\title{
Concentration of Isotopes of Chlorine by the Counter- current Electromigration Method
}

\author{
By Samuel L. Madorsky and Sidney Straus
}

\begin{abstract}
The isotope ${ }^{35} \mathrm{Cl}$ was concentrated in the anode compartment of an electromigration cell, with $\mathrm{NaCl}$ as the electrolyte. The operation was regulated by means of a stationary boundary between solutions of $\mathrm{NaOH}$ and $\mathrm{NaCl}$ as the lower and upper liquids, respectively. A concentration of ${ }^{35} \mathrm{Cl}$ from the normal value of 75.76 percent to a maximum value of 80.7 percent was obtained in 474 hours. The maximum initial separation coefficient, $\epsilon-1$, was $0.207 \times 10^{-2}$.
\end{abstract}

\section{Introduction}

Kendall and Crittenden [1] ${ }^{2}$ attempted to separate the isotopes of chlorine by the ionicmigration method. They transported chlorine ions in a tube filled with agar-agar through a distance of 100 feet by means of a moving bou ddary. An atomic-weight determination of chlorine in the forward section of the gel failed to detect any change in the isotope ratio. More recently, a new method [2] based on the principle of countercurrent electromigration, has been developed at the National Bureau of Standards for the separation of isotopes. The successful application of this method to the concentration of ${ }^{39} \mathrm{~K}$ and ${ }^{41} \mathrm{~K}$ [3] from solutions of $\mathrm{K}_{2} \mathrm{SO}_{4}$ and $\mathrm{KCl}$ suggested the possibility of concentrating the isotopes of chlorine by this method. The present paper describes some experiments designed to concentrate ${ }^{35} \mathrm{Cl}$ from a solution of $\mathrm{NaCl}$.

\section{Outline of Problem}

Chlorine appears in nature as a mixture of 75.4 percent ${ }^{35} \mathrm{Cl}$ and 24.6 percent ${ }^{37} \mathrm{Cl}[4]$. In an electromigration cell ${ }^{35} \mathrm{Cl}$ - can be concentrated in the anode compartment, provided the original

${ }^{1}$ This paper will appear in volume 6 , division III, of the Manhattan Project Technical Series.

${ }_{2}$ Figures in bracket indicate the literature references at the end of this paper.

isotopic ratio is maintained in the cathode compartment. However, if the chloride ion is allowed to react at the anode to form chlorine gas, it will escape. This raction was prevented by interposing a solution of sodium hydroxide around the anode to form a boundary between the chloride and hydroxide solutions.

Sodium chloride in the ratio $\mathrm{NaCl}: \mathrm{H}_{2} \mathrm{O}=1: 30$ was used as the electrolyte. As the transport numbers of $\mathrm{Na}^{+}$and $\mathrm{Cl}^{-}$are approximately 0.40 and 0.60 , respectively, the anode restituent was 1:18 NaOH, whereas the cathode restituent was $1: 12 \mathrm{HCl}$. Characteristic properties of the solutions employed are shown in table 1. As seen from this table, $1: 18 \mathrm{NaOH}$ has a greater density than $1: 30 \mathrm{NaCl}$, and, therefore, the alkali solution should be the lower layer, and the salt solution should be the upper layer at the anode boundary. Such an arrangment is shown in the gooseneckshaped anode compartment in figure 1.

TABLE 1.- Solutions employed in the chlorine electromigration experiments

\begin{tabular}{|c|c|c|c|c|}
\hline Solute & $\begin{array}{l}\text { Ratio } \\
\text { solute }: \mathrm{H}_{2} \mathrm{O}\end{array}$ & $\begin{array}{l}\text { Concen- } \\
\text { tration }\end{array}$ & $\begin{array}{l}\text { Density } \\
\text { at } 25^{\circ} \mathrm{C}\end{array}$ & Normality \\
\hline $\mathrm{NaCl}$ & $1: 30$ & $\begin{array}{r}\text { Percent } \\
9.76\end{array}$ & 1. 067 & 1. 782 \\
\hline $\mathrm{NaOH}$ & $1: 18$ & 10.98 & 1.118 & 3.067 \\
\hline $\mathrm{HCl}_{\ldots} \ldots$ & $1: 12$ & 14. 43 & 1. 068 & 4. 225 \\
\hline
\end{tabular}




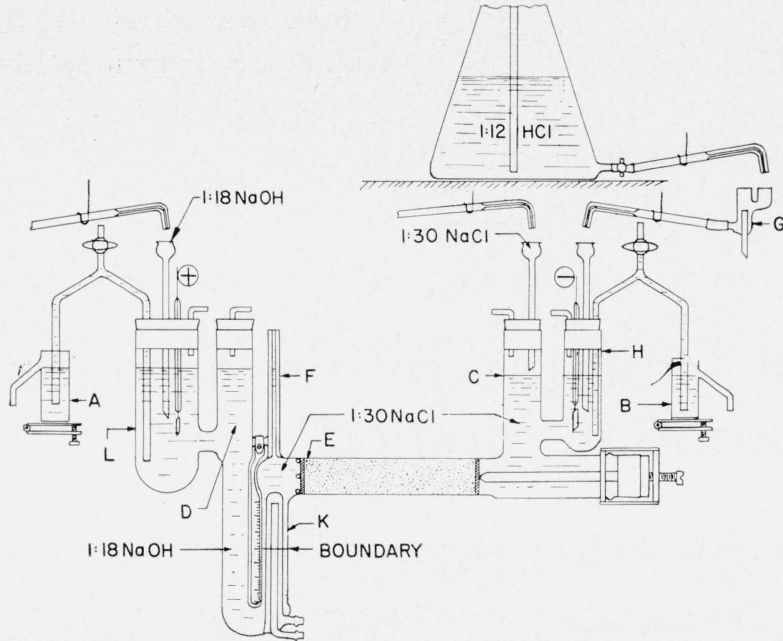

FIgURE 1.-Diagram of electromigration cell used in the chlorine experiments.

\section{Apparatus and Experimental Procedure}

The apparatus is shown diagrammatically in figure 1 and photographically in figure 2 . The packing was $2 \mathrm{~cm}$ in diameter and $10 \mathrm{~cm}$ long. It consisted of No. 107 ballotini glass beads in experiment 1 and of 60- to 100-mesh Ottawa sand in the other experiments. The packing supports

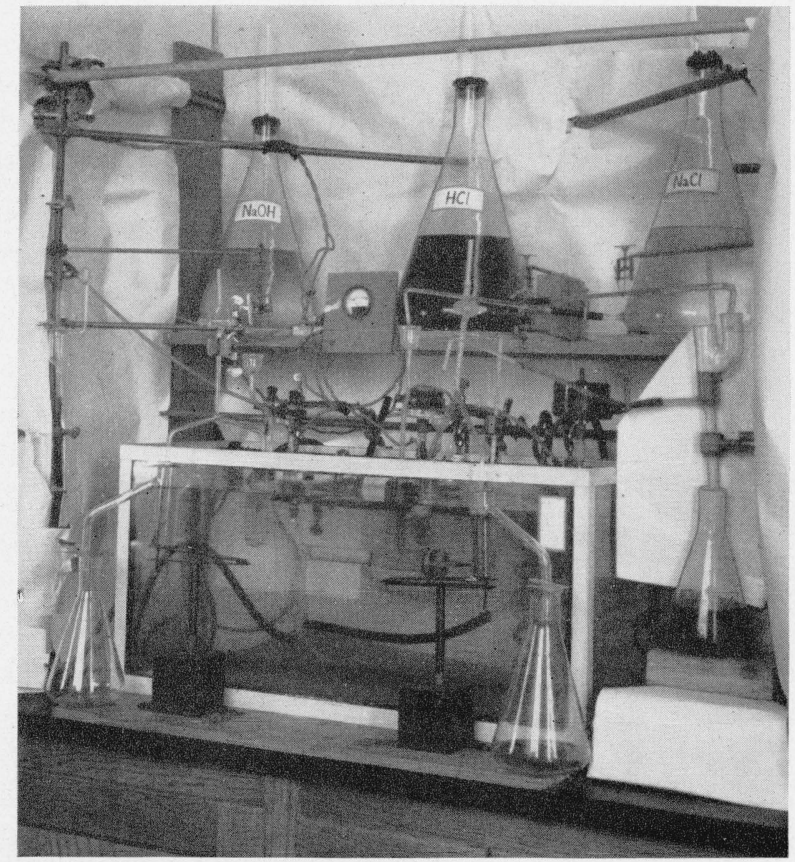

FIGURE 2.-Electromigration cell assembly showing dropper and constant level devices. were No. 40 bead frits. At the anode end the frit was held in place by means of a sealed-in glass cross, and at the cathode end it was supported by means of a screw and a glass rod passing through a rubber stopper. In experiments 2 and 3 , frits similar to those at the ends of the packed column were also placed in the packing at intervals of about $3 \mathrm{~cm}$ in order to impart greater rigidity to the compressed sand. The wall thickness of the packed tube was $1 \mathrm{~mm}$. The electrode sections were supplied with manually controlled droppers, siphons, and manually controlled overflow cups ( $A$ and $B$, fig. 1). The cathode was of the flushed type receiving $1: 30 \mathrm{NaCl}$ solution in addition to a stoichiometric amount of $1: 12 \mathrm{HCl}$. The electrodes were made of platinum gauze, about 4 $\mathrm{cm}^{2}$ in area.

The boundary was maintained between $1: 30$ $\mathrm{NaCl}$ and 1:18 $\mathrm{NaOH}$ as the upper and lower liquids, respectively, in an annular space, $K$, between the outer tube and the inside cooler, as shown in figure 1. The boundary ring had an inside diameter of $13 \mathrm{~mm}$, was $1.5 \mathrm{~mm}$ wide, and had a total area of $0.6 \mathrm{~cm}^{2}$. The anode volume, i. e., the volume of liquid between the boundary and the packing, was about $10 \mathrm{ml}$. The boundary is shown in figure 3. Pertinent data of all the experiments are shown in table 2 .

TABLE 2.-Experimental details and results

\begin{tabular}{|c|c|c|c|c|}
\hline $\begin{array}{c}\text { Experiment } \\
\text { No. }\end{array}$ & Packing & $\begin{array}{c}\text { Poten- } \\
\text { tial }\end{array}$ & $\begin{array}{c}\text { Anode } \\
\text { volume }\end{array}$ & $\underset{(\epsilon-1) \times 10^{2}}{\text { Initial }}$ \\
\hline 1. & 100-mesh ballotini gless beads, & $\begin{array}{l}a m p \\
0.430\end{array}$ & \begin{tabular}{l|}
$m l$ \\
10.4
\end{tabular} & 0.115 \\
\hline 2 & $\begin{array}{l}\text { 60- to } 100 \text {-mesh sand, } 3 \text { inter- } \\
\text { mediate frits. }\end{array}$ & .430 & 10.4 & .128 \\
\hline 3. & _... do do & .430 & 11.0 & .180 \\
\hline $4 \ldots$ & $\begin{array}{l}\text { 60- to } 100 \text {-mesh sand, no inter- } \\
\text { mediate frits. }\end{array}$ & .500 & 11.0 & .207 \\
\hline $5 \ldots$ & ..... do & .500 & 11.0 & .183 \\
\hline
\end{tabular}

In filling the cell, 1:18 $\mathrm{NaOH}$ solution was first poured into the anode compartment to the level where the boundary was expected. Sodium chloride solution (1:30) was then poured into the cathode compartment and allowed to seep through the packing into the anode volume space $E$ (fig. 1). Further additions of $\mathrm{NaOH}$ solution kept the junction between the two liquids in the neighborhood where the boundary was desired. After the cell was filled to the proper levels, the current was turned on and the addition of restituents 


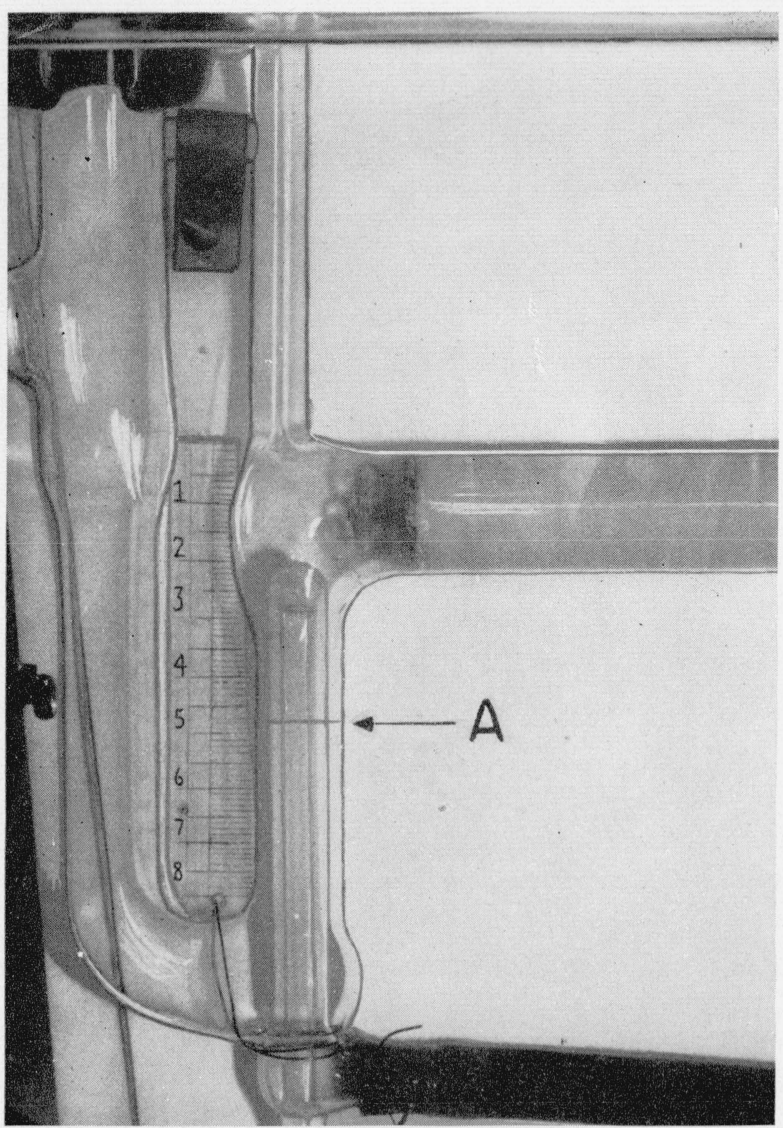

Figure 3.-Details of cathode compartment. $A$, Boundary

started. A sharp boundary appeared within a few minutes.

The current in all the experiments was about $0.5 \mathrm{amp}$ and the voltage between the electrodes about 80 .

The operation was continuous, requiring little attention. In the daytime, drop rates were adjusted two to three times, while during nights the cells were left without attention. Fluctuations of the boundary level during off-duty periods were generally within $1 \mathrm{~cm}$, but occasionally it would reach a maximum of $2 \mathrm{~cm}$. As the cross section of the annular space, $K$ (fig. 1), was $0.6 \mathrm{~cm}^{2}$, a 1 - to 2 -cm variation of the boundary level corresponded to about 5 to 10 percent in anode volume, $V_{a}$. Variations of drop rates were chiefly caused by changes in room temperature.

The chlorine electromigration cells seemed to be more sensitive to the $\mathrm{pH}$ condition of the cathode, i. e., to the rate of addition of $\mathrm{HCl}$ than to the rate of addition of $\mathrm{NaOH}$ or $\mathrm{NaCl}$. In order to control the acid rate more closely, it was first fed into a constant overflow cup, $G$ (fig. 1), and from there into the cathode compartment $H$ through manually controlled droppers. The cells operated best when the cathode overflow from $B$ was slightly acid, as was indicated by methyl red introduced with the $\mathrm{HCl}$ restituent. The stoichiometric amounts of $\mathrm{HCl}$ and $\mathrm{NaOH}$ solutions required per ampere hour are 9.4276 and $13.5902 \mathrm{~g}$, respectively. The actual amount of $\mathrm{HCl}$ added was slightly in excess of that required theoretically. For $\mathrm{NaOH}$ an excess of about $20 \mathrm{~g}$ per ampere hour was used. This excess was bypassed through a siphon, as shown in figure 1 . The amount of cathode flushing restituent, $\mathrm{NaCl}$, added was $24 \mathrm{~g}$ per ampere hour. The cells under normal operation ran slightly alkaline above the boundary and through the packing column, as was indicated by methyl red fed into the anode with the $\mathrm{NaOH}$ restituent.

As a check on the operation of the cells, analyses of the anode and cathode overflow liquids, as well as of samples drawn from various parts of the cell, were made at intervals. Overflow liquid from $A$ (fig. 1) and samples drawn from $D$ were analyzed for $\mathrm{NaOH}$. Overflow liquid from $B$ was analyzed for $\mathrm{NaCl}$ and $\mathrm{HCl}$, and samples drawn from $C$ were analyzed for $\mathrm{NaCl}$ and $\mathrm{NaOH}$. No chlorine was found either in cup $D$ or in the anode overflow

TABLE 3.-Analysis of cell and overflow liquids in experiments 2 and 3

\begin{tabular}{|c|c|c|c|c|c|c|}
\hline \multirow{2}{*}{$\begin{array}{l}\text { Hours } \\
\text { after } \\
\text { start }\end{array}$} & \multirow{2}{*}{$\begin{array}{l}\text { Over- } \\
\text { flow } \\
\text { from } A, \\
\text { NaOH }\end{array}$} & \multirow{2}{*}{$\begin{array}{l}\text { Liquid } \\
\text { from } \\
\text { cup } D, \\
\text { NaOH }\end{array}$} & \multicolumn{2}{|c|}{ Overflow from $B$} & \multicolumn{2}{|c|}{ Liquid in cup $C$} \\
\hline & & & $\mathrm{NaCl}$ & $\mathrm{HCl}$ & $\mathrm{NaCl}$ & $\mathrm{NaOH}$ \\
\hline \multicolumn{7}{|c|}{ EXPERIMENT 2} \\
\hline & $\%$ & $\%$ & $\%$ & $\%$ & $\%$ & $\%$ \\
\hline 0 & 10.95 & 10.95 & 9.76 & & 9.76 & 0 \\
\hline 65 & 10.15 & (n) & 9.93 & .21 & 10.87 & .24 \\
\hline 137 & 9.34 & 10.58 & & & & ... \\
\hline 209 & 10.24 & & 10.02 & .40 & 10.91 & .23 \\
\hline 305 & 10.30 & & 10.05 & .30 & 10.86 & .22 \\
\hline 411 & 10.09 & & 9.94 & .43 & 10.88 & .22 \\
\hline \multicolumn{7}{|c|}{ EXPERIMENT 3} \\
\hline 0 & 10.95 & 10.95 & 9. 76 & 0 & 9.76 & 0 \\
\hline 69 & 10.88 & & 9.77 & .93 & 9.76 & .52 \\
\hline 93 & 10.55 & 10.64 & n & & & \\
\hline 237 & -10.57 & - & 9.87 & .25 & 10.43 & .22 \\
\hline 309 & 10.39 & & 9.75 & .48 & 10.31 & .20 \\
\hline 405 & 10.31 & & 9. 79 & .32 & 10.25 & 23 \\
\hline 501 & 10.53 & -... & 9.99 & .17 & . & \\
\hline
\end{tabular}


liquid. As an illustration, analyses for experiments 2 and 3 are shown in table 3 .

As seen from this table, there was little change in the composition of the liquids in the cells during operation.

\section{Mass-Spectrometer Analysis And Interpretation of Resulrs}

A sample of liquid weighing about $0.2 \mathrm{~g}$ was drawn from the anode volume, $E$, by inserting a capillary through a small tube, $F$ (fig. 1). In preparing the sample for analysis in the mass spectrometer, it was placed through $A$ in leg $B$ of the specially designed sampler shown in figure 4 and evaporated to dryness. About 0.3 to $.05 \mathrm{ml}$ of concentrated $\mathrm{H}_{2} \mathrm{SO}_{4}$ was then placed in leg $C$ of this sampler, the latter connected to a vacuum system through ground-glass joint $E$, and highly evacuated. Stopcock $D$ was then closed and the sampler removed from the vacuum system. Before attaching the sampler to the mass spectrometer by means of $E$, it was tilted so as to allow the $\mathrm{H}_{2} \mathrm{SO}_{4}$ to flow from leg $C$ into leg $B$. The $\mathrm{HCl}$ formed in the reaction between $\mathrm{NaCl}$ and $\mathrm{H}_{2} \mathrm{SO}_{4}$ was then analyzed for the isotopes of chlorine. The analyses were carried out in a Consolidated mass spectrometer.

$\downarrow$ Concentration of ${ }^{35} \mathrm{Cl}$ in ordinary chlorine was measured in five samples of chemically pure $\mathrm{NaCl}$ as follows:

\begin{tabular}{|c|c|}
\hline Analysis No. & ${ }^{35} \mathrm{Cl}$ \\
\hline $1 \ldots$ & $\begin{array}{c}\text { Percent } \\
75.74\end{array}$ \\
\hline 2 & 75.73 \\
\hline 3. & 75.79 \\
\hline $4 \ldots$ & 75.74 \\
\hline 5 & 75.79 \\
\hline A verage & 75.76 \\
\hline
\end{tabular}

From the above ratio, $R_{0}=N_{1} / N_{2}={ }^{35} \mathrm{Cl} /=3.12$

The results are shown in table 4 in terms of percentage of ${ }^{35} \mathrm{Cl}$, ratio $R_{t}=N_{1} / N_{2}$ at time $t$ and separation factor $R_{t} / R_{0}$. Figure 5 shows concentration of ${ }^{35} \mathrm{Cl}$ plotted against time in hours.

The separation coefficient, $\epsilon$, was calculated by means of eq 10 of RP1765 [3].

$$
\frac{I^{-} t(\epsilon-1) N_{1} N_{2}}{F}=\frac{V_{a} C}{1,000} \times \frac{R_{t}-R_{o}}{\left(R_{t}+1\right)\left(R_{o}+1\right)},
$$

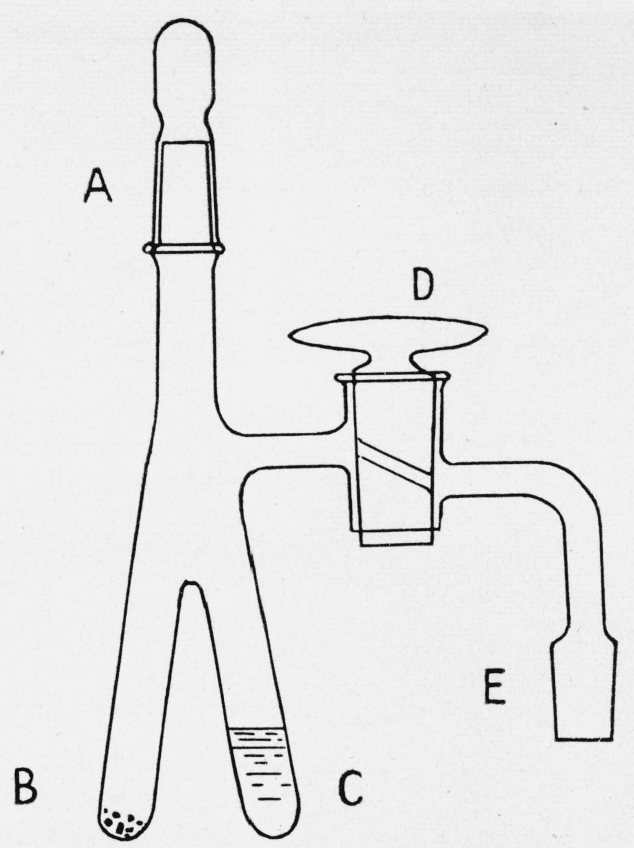

Figure 4.- Sample tube used in mass-spectrometer analysis of ratio of chlorine isotopes.

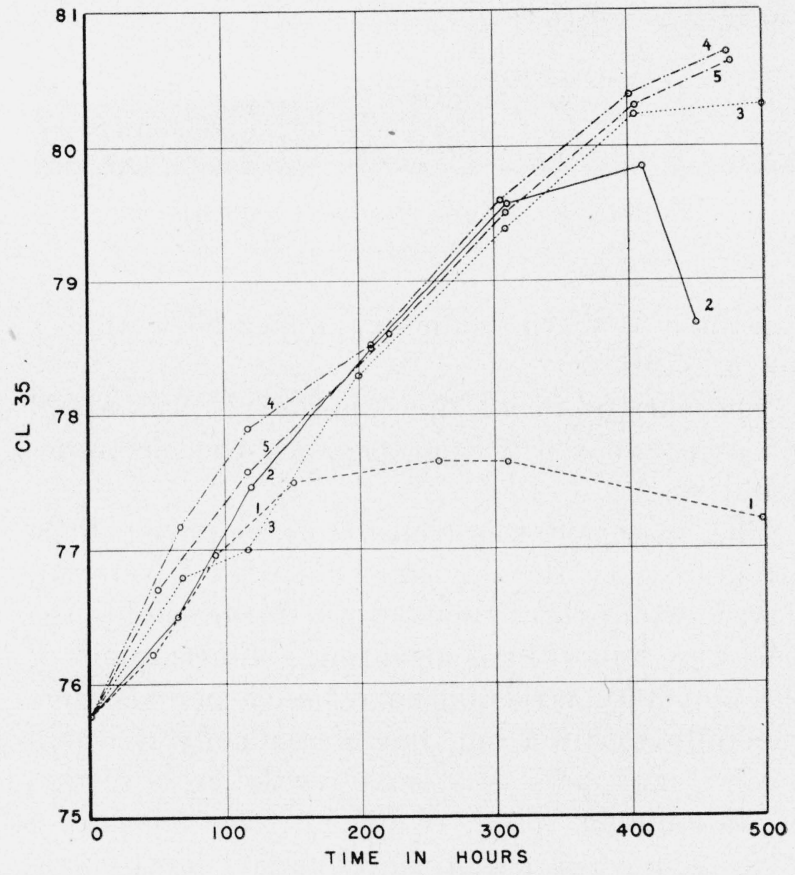

Figure 5.-Curves showing increase in percentage of ${ }^{35} \mathrm{Cl}$ with time in five similar experiments.

where

$I^{-}=$negative current $=$total current $I$ times chlorine transport number $T_{\mathrm{Cl}}$, which in this case is 0.6

$t$ =time in seconds 
$V_{a}=$ anode volume

$C=$ normality of $\mathrm{NaCl}$ solution $=1.782$

$F=$ Faraday constant.

The above equation can be written in the following simplified form:

$$
\epsilon-1=0.03543 \frac{V_{a} C}{I^{-} t_{1}} \times \frac{R_{1_{\mathrm{t}}}-3.12}{R_{t_{1}}+1}
$$

where $t_{1}$ is time in hours. The values for $\epsilon-1$ are shown in the last column of table 4 .

TABLE 4.-Concentration of ${ }^{35} \mathrm{Cl}$ and separation coefficient

\begin{tabular}{|c|c|c|c|c|c|}
\hline $\begin{array}{l}\text { Experiment } \\
\text { No. }\end{array}$ & $\begin{array}{l}\text { Hours } \\
\text { after } \\
\text { start }\end{array}$ & ${ }^{35} \mathrm{Cl}$ & $R_{\mathrm{s}}={ }^{35} \mathrm{Cl} /{ }^{37} \mathrm{Cl}$ & $\begin{array}{c}\text { Separa- } \\
\text { tion fac- } \\
\text { tor, } R_{t} / R_{0}\end{array}$ & $(\epsilon-1) \times 10^{2}$ \\
\hline \multirow{7}{*}{$1 .}$. & 0 & $\begin{array}{r}\text { Percent } \\
75.76\end{array}$ & 3. 12 & 1.000 & \\
\hline & 46 & 76.22 & 3. 21 & 1.029 & 0.115 \\
\hline & 92.5 & 76.96 & 3. 34 & 1.071 & .136 \\
\hline & 152 & 77.50 & 3.44 & 1.103 & .117 \\
\hline & 259 & 77.65 & 3.47 & 1.112 & .075 \\
\hline & 312 & 77.64 & 3.48 & 1.115 & .064 \\
\hline & 499 & 77.21 & 3.39 & 1.087 & .031 \\
\hline \multirow{6}{*}{$2 .}$. & 65 & 76.50 & 3. 26 & 1.045 & 0.128 \\
\hline & 120 & 77.47 & 3.44 & 1.103 & .152 \\
\hline & 209 & 78.50 & 3.65 & 1.170 & .138 \\
\hline & 310.5 & 79.57 & 3. 89 & 1. 247 & .128 \\
\hline & 411 & 79.85 & 3. 96 & 1. 269 & .104 \\
\hline & 450 & 78.68 & 3. 69 & 1. 183 & .068 \\
\hline \multirow{6}{*}{3.} & 69 & 76.80 & 3. 31 & 1. 061 & 0.180 \\
\hline & 117 & 77.00 & 3.35 & 1. 074 & .127 \\
\hline & 200 & 78.30 & 3.61 & 1.157 & .150 \\
\hline & 309 & 79. 39 & 3.85 & 1. 234 & .137 \\
\hline & 405 & 80.23 & 4. 06 & 1.301 & .129 \\
\hline & 501 & 80.31 & 4. 08 & 1.308 & .106 \\
\hline \multirow{6}{*}{4} & 66.5 & 77.17 & 3. 38 & 1. 083 & 0.207 \\
\hline & 118 & 77. 90 & 3.52 & 1.128 & .174 \\
\hline & 209 & 78.52 & 3.66 & 1.173 & .128 \\
\hline & 305 & 79.60 & 3.90 & 1. 250 & .121 \\
\hline & 402 & 80.38 & 4.10 & 1.314 & .111 \\
\hline & 474 & 80.70 & 4.18 & 1.340 & .100 \\
\hline & 50 & 76.71 & 3. 29 & 1. 055 & 0.183 \\
\hline & 118 & 77.58 & 3.46 & 1.109 & .150 \\
\hline & 222 & 78.61 & 3.68 & 1.180 & .125 \\
\hline & 309 & 79. 51 & 3. 88 & 1. 244 & .117 \\
\hline & 405 & 80.30 & 4.08 & 1.308 & .108 \\
\hline & 477 & 80.63 & 4. 16 & 1. 333 & .98 \\
\hline
\end{tabular}

\section{Conclusions}

Glass-bead packing did not stand up well because of the alkaline nature of the anode, as seen from results of experiment 1. Sand, on the other hand, stood up well, as shown by the result of experiments 2 to 5 , inclusive. Inserting fritted disks in the packing in experiments 3 and 4 did not seem to make any difference, as is evident by comparing the results of these experiments with those of experiments 4 and 5 . Results of all the experiments (in case of experiment 1, up to $150 \mathrm{hr}$ ) are in good agreement. At about 400 hours, the curves (fig. 5) begin to drop. This is due to the accumulation at the anode end of the packing of silica gel resulting from the action of $\mathrm{NaOH}$ on the glass. A close examination of figure 3 shows a jelly-like mass in front of the anode end of the packing. The highest separation was obtained in experiment 4, where the concentration of ${ }^{35} \mathrm{Cl}$ changed from 75.76 to 80.70 percent, after 474 hours of operation, representing an increase of 4.94 percent.

The initial $\epsilon^{-1}$ for the first 50 to 70 hours varies from 0.0115 to 0.0207 . There is in every case a tapering off of these values with time, due undoubtedly to the accumulation of ${ }^{35} \mathrm{Cl}$ in the packing caused by diffusion and fluctuation of the boundary.

The authors thank V. H. Dibeler and Dorothy Thompson for making the mass-spectrometer analyses reported in this paper.

\section{References}

[1] James Kendall, Science 67, 163 (1928).

[2] A. Keith Brewer, Samuel L. Madorsky, and James W. Westhaver, Science 104, 156 (1946).

[3] A. Keith Brewer, S. L. Madorsky, et al., The concentration of isotopes of potassium by the countercurrent electromigration method, J. Research NBS 38, 137 (1947) RP1765.

[4] Sixth Report of the Committee on Atoms of the International Union of Chemistry (1941-42).

Washington, August 5, 1946. 